\title{
The Governors' Last Stand: Federal Bargaining in Russia's Transition to Appointed Regional Heads, 2005-2009
}

\author{
Helge Blakkisrud \\ Oslo: Universitetet i Oslo, Institutt for statsvitenskap 2015 \\ 416 sidor. ISSN 15043991
}

Recenserad av Peter Söderlund [Akademiforskare vid Institutet för Samhällsforskning, Åbo Akademi, Finland, peter.soderlund@abo.fi]

Ett intrikat skådespel med den ryska centralmakten och regionala makteliter som aktörer har spelats upp under ett kvartssekel i Ryssland. Rysslands president har periodvis strävat efter att stärka Moskvas makt i förhållande till regionerna. Det sätt på vilket regionala presidenter och guvernörer tillsätts - endera via direkta folkval eller på initiativ av Moskva - har haft stor betydelse för maktförhållandet mellan centrum och regionerna.

I sin doktorsavhandling bidrar Helge Blakkisrud med intressanta inblickar i och tolkningar av maktförhållandet mellan den ryska centralmakten och regionerna. Fokus i avhandlingen ligger på perioden 2005-2009 då en maktförskjutning till Moskvas fördel skedde. Under denna övergångsprocess övergick man från folkvalda regionala presidenter och guvernörer till av Rysslands president utvalda ämbetsmän. Denna nya praxis var en del av det centraliseringspaket (andra i ordningen) som presenterades av president Vladimir Putin år 2004.

För att förstå betydelsen av denna federala reform bör man vara medveten om att pendeln mellan centralisering och decentralisering har svängt under årens lopp. Efter Sovjetunionens fall fanns såväl folkvalda som av centralmakten utnämnda regionala ledare. Mellan 1996 och 2004 utsågs regionala ledare i regel via direkta folkval. Från och med 2005 tog sig Rysslands president rätten att nominera regionala exekutiva ledare, medan de regionala parlamenten formellt godkände utnämningarna. I praktiken var det Kreml som utsåg och avsatte regionala exekutiva ledare; de regionala parlamenten fungerade som gummistämplar. Intressant nog avsade sig president Dimitri Medvedev denna rätt från och med 2012, delvis på grund av massdemonstrationer där vissa krav gällde rätten till att rösta i fria, demokratiska och öppna val.

Boken är en typisk akademisk avhandling med ett introduktionskapitel där bakgrund, syfte och mål presenteras. Kapitel 2 består av en teoretisk introduktion som behandlar federalism och federala relationer i allmänhet samt förhandlingsprocesser mellan centrum och regioner i Ryssland. I kapitel 3 finns en bra historisk återblick av hur regionernas maktposition har förändrats i Ryssland sedan 1990-talet. Kapitel 4 avhandlar ingående det nya systemet med utnämningar av regionala exekutiva ledare från och med 2005. 
Den empiriska analysen sker i två steg i syfte att försöka förklara vem av de regionala ledarna som fick förnyat förtroende och vem som ersattes. Drygt hälften av de 89 personerna som innehade ämbetet innan reformen hade ersatts vid utgången av 2009. Utgångspunkten för analysen är att de regionala cheferna för de verkställande myndigheterna befunnit sig i olika förhandlingspositioner i sin strävan att förlänga sin tid vid makten genom att vinna presidentadministrationens gunst. Betydelsen av såväl personliga resurser (kapitel 5) som fördelningen av strukturella resurser knutna till regionerna (kapitel 6) testas.

Ett av avhandlingens centrala resultat är att personer med bakgrund i polis, militär och säkerhetstjänst inte hade någon fördel. Snarare var det så att industri- och affärsmän, med senare erfarenhet av politiska och administrativa tjänster på federal eller regional nivå, var mer benägna att rekryteras till guvernörsposterna. I viss mån skedde en generationsväxling $\mathrm{i}$ och med att några regionala ledare som suttit vid makten sedan 1990-talet ersattes. Vikten av lokal förankring tycks också ha minskat i och med att andelen guvernörer födda och verksamma utanför regionerna ökade. Ett annat centralt resultat är att presidenter och guvernörer i folkrika och ekonomiskt tunga regioner fick fortsatt förtroende. Detta kan tolkas som att betydelsen av strukturella maktresurser fortsätter spela en viktig roll inom ramen för rysk federal politik.

Helge Blakkisruds avhandling är väl strukturerad med en bra balans mellan det specifika och det generella. I rätt detaljerade ordalag lyfts såväl lagförändringsprocesserna som flera regionala ledares öden fram. Samtidigt lyckas författaren med att lyfta blicken och finna allmängiltiga förklaringar till varför vissa presidenter och guvernörer fick fortsatt förtroende medan andra inte fick det. Tabellerna är inte alltid lätta att tolka, men tack vare att det kontinuerligt förekommer sammanfattningar är det lätt för läsaren att hänga med i författarens resultattolkningar. Summa summarum, boken utgör ett betydelsefullt bidrag för att förstå rysk federalism och inrikespolitik. 